\title{
STUDIES ON APPLE POLLINOSIS.
}

\author{
MASARU HAKAMADA, M. D. \\ Department of Otolaryngology, Hirosaki University School of Medicine, Hirosaki
}

(Director: J. Hozawa, M. D.)

The twenty-one patients with apple pollinosis in Aomori prefecture (Japan) were reported in this paper.

These patients (male : 7 , female : 14) showed typical symptoms of allergic rhinitis (100\%), conjunctivitis (100\%), pharyngitis $(38.1 \%)$, dermatitis $(28.6 \%)$ and persistent cough (33.3\%). These symptoms appeared at the flowering time of apple tree and was observed during the pollination work in the apple farm.

17 patients out of the 21 cases were farmers engaged in the apple pollination work for 725 years. Other 4 patients have lived near the apple farm. Thus, the contact with large amount of apple pollen was thought to be the cause of the sensitization.

Generally speaking, these patients had severe nasal symptoms and eosinophilia in nasal secret, and showed high sensitivity to the apple pollen in the intradermal test and the provacation test to the nasal mucosa.

However, $\operatorname{IgE}$ value by RIST (mean value : $484 \mathrm{u} / \mathrm{m} l$ ) showed no seasonal change, and the value of IgE antibodies by RAST was lower than those of the other pollinosis, though it was determined as positive. The desensitization therapy with apple pollen antigen extract was effective.

From results of the questionnaire study to apple farmers in Aomori prefecture, $7.34 \%$ of the answerer ( 5240 cases) were suspected as apple pollinosis.

A $83-0036-32879$

\section{リンゴ花粉症の研究}

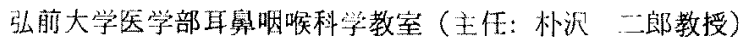

袴田勝

\section{1 緒 言}

以前より青森県下では，リンゴ開花期に一致して舀厂 レルギー症状を訴える者が多数認められたが，原因不明 として放置されたままであったところが，1974年リン ゴ化粉症（以下，本症と略す）の1例が発見されて以来 1，县内各所での報告が相次ざ，しが，症例はりンゴ 農業従軎者およびりンゴ固付近の住民に限られているこ

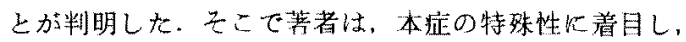

リンゴ花粉空中我散調查, リンゴ譨業従事者を対象上し た䝿アレルギー检診を行ならと共に，現在までに発見さ れた本症21症例に対し，磨アレルギ一を中心とした臨床 的見地より检尉を加えてみた。

\section{II リンゴとその花粉}

リンゴ (Malus pumila Mill. var. demestica C. K. Schn）は被子艋物重門，双子葉絧，バラ科嘱する落葉 
性の高木で，開花中の花并は白色5 枚，雄しべは20本前 後，子房は花床で包まれ，花柱は5 本に分かれる。自家 不和合性が強いため，結実させると注他品種を混植する 加，他品種花粉を人工交配（人工受枌）しなければなら ない。

栽培分布は広範で，年平均気温が $4-6^{\circ} \mathrm{C}$ の地域に加 たって敌り，代表的生産国はフランス，アメリカ，イタ リア，西ドイッ，日本て，本邦ては青湘県が最大生産量 を占め，長野，岩手，北海道，山形，秋田，福島の㮌で

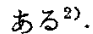

青森紧に打ける1979年のリンゴ栽培面積は 22,662 ha に怙よび，その86\%が人工交配を予定しており，生徒， 自衛隊員を中心に 25,118 人の援農を見込むと共に，ミッ バ千導入計画も9,473群となっている゙3。青森紧下のリ ンゴ閉花期は例年 5 月上旬上り 5 月末までであるが，気 象条件の变化により20日前後のずれが生ずる.1979年は 5 月15日頃より開花しはじめ，5月20日には全具下満開 状热であった（写真 1).

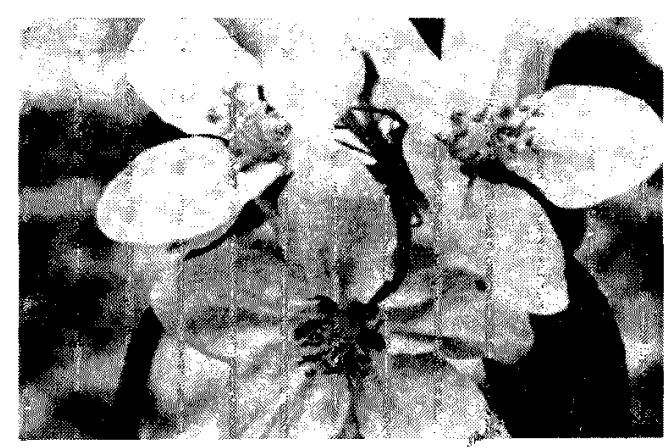

写真 1 リンゴ (Malus pumila Mill. var. demestica C. K. Schn) の開花状態. 弘 前市内のリンゴ園にて撮影

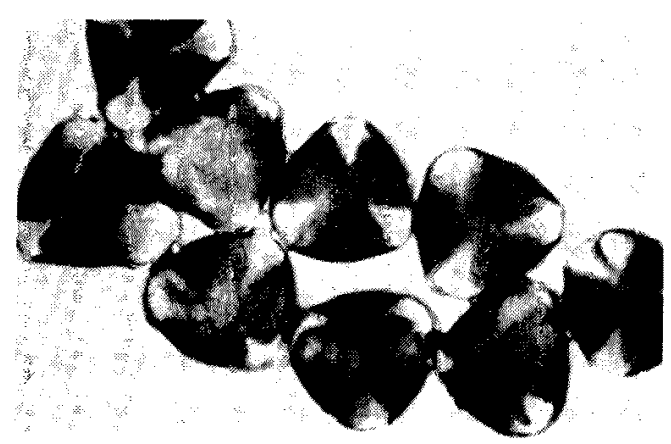

写真 2 リンゴ花粉の光学顕㣲镜写真（カルベ 亏染色 $\times 400$ 拡大)
リンゴ花粉は幾瀬氏の分類 状紋に禹し，その大き性湿閏状热て $28-30 \mu ， 3$ 力所 の発芽口のうち，普通は1力所より花粉管が伸長してく

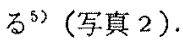

\section{IIIリンコ花粉空中飛散状況}

リンゴ化枌空中飛散調查は1978年5月1日より5月31 日までは弘前大学医学部䧗床研究楝屋上（リンゴ囷より 約 $1 \mathrm{~km}$, 地上䄪 $15 \mathrm{~m}$, 以下 研究棟屋上之略す) と弘前 市旭ガ丘尜藤宅二階ベランダ（リンゴ園上り䄪 $30 \mathrm{~m}$ ，地 上約 $4 \mathrm{~m}$ ，以下斎藤宅と略す）て実施し，1979年 4 月20 日より6月5日荌では，研究㷄屋上と研究棟三階前芝生 (地上約 $30 \mathrm{~cm}$, 以下 研究棟下上略す)，並び飞弘前市樹 木高木宅一階ベランダ（リンゴ園より約 $10 \mathrm{~m}$ ，地上約 15 $\mathrm{cm}$ ，以下高木宅之格す）にて実施した．4実施地点共に

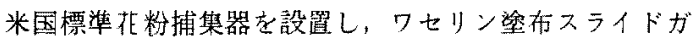
ラ又を連日24時間敏江父換し，Calverla 液て染色後に鏡

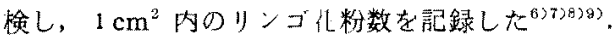

1978年のリンゴ花粉空中飛散は, 研究棟屋上では 5 月 7 日より5月30日までで，リンゴル粉空中飛散総数は188 個 $/ \mathrm{cm}^{2}, 1$ 日平均は 6.06 個 $/ \mathrm{cm}^{2}$ で，5月23日には55個 $/ \mathrm{cm}^{2}$ の最竦値を記録した。一方，リンゴ園より約 $30 \mathrm{~m} の$ 斎藤宅では，5月4日より5月30日荠で形散し，空中我 㪄総数は 240 個 $/ \mathrm{cm}^{2}, 1$ 日平均は 8.89 倜 $/ \mathrm{cm}^{2}$ で， 5 月 22 日に 57 個 $/ \mathrm{cm}^{2}$ の最高值を記録した ${ }^{10)}$.

1979年のリンゴ花粉空中飛散は, リンゴ園より約 $10 \mathrm{~m}$ の高木宅では 5 月11日上り始まり，5月24日江28個 $/ \mathrm{cm}^{2}$ の最高值を記録し，6月4日飞終了，調查期間中の空中 花粉総数ば142個/ $\mathrm{cm}^{2}$ であった。また，研究棟屋上は 5 月12日より5月29日まで飛散がみられ，研㚾槙下では 5 月11日より6月 3 日まて飛散がみられた。共江棘状のグ ラフパターンを示したが，最高空中花粉数が研究㨂屋上 では 10 腘 $/ \mathrm{cm}^{2}$ ，时究棟下では 23 個 $/ \mathrm{cm}^{2}$ ，また，空中化 粉衿数は研究棟屋上ては 29 個 $/ \mathrm{cm}^{2}$ ，研究棟下では. 43 個 $1 \mathrm{~cm}^{2}$ と，低地の方飞多くの飛散をみた。

1978年に対し1979年はリンゴ開花期間が短く，その北 粉飛散状㳂む前年とは異学っていると思うが，低地への 飛散が多く，リンゴ園より $1 \mathrm{~km} の$ 地点でも花粉飛散は 認められる方，そのグラフパターンが棘状であることな どを考えあわせると，1979年のリンゴ化粉哲中飛散曲線 が蝶花であるリンゴの典型的パターンと思穴た（第 1 国). 


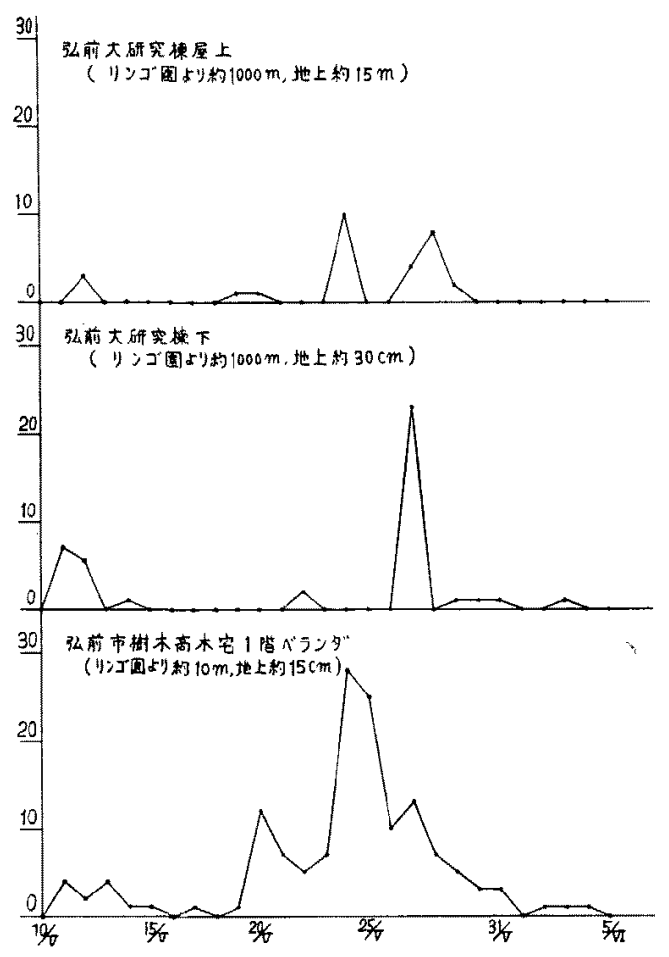

図 1 リンゴ花粉空中飛散曲線（1979年）

\section{V アンケート調查と検診}

リンゴ花粉に最も感作されやすい環境下にあるのはリ ンゴ農業従事者であらうとの観点より，1978年 3 月に青 森舆黒石市在住リンゴ農業徒事者 1,892世带 2,067名と 平賀町在住りンゴ農業従事者 1,484 世带 3,173名，合計 3,376世帯 5,240名を対象として，リンゴ花粉症アンケ 一ト調查を行なった，第1表に示すアンケート用紙を世 帯每汇配布し，1力月後に回収した.

回収率は $35.1 \%(1$ ，185世带）で，リンゴ開花期に鼻 アレルギー症状が発現する人のいる世带は 173世帯で回 答数の $14.6 \%$ にあたり，両地区間に有意差を認めなか った。しかむ，これらの症状が数年間持続して同時期に なると発現する人のいる世带は134世带385人であり， 回答者数の $7.34 \%$ 凡䠹当した。

以上の134世帯のリンゴ農業従事者に対するアレルギ 一症状発現時刻，場所，期間についてのアンケート結果 は, 日中が 82 世帯 $(61.2 \%), 1$ 日中が 32 世带，朝方 13世带, 夕方8世炗, 晚 2 世带であり，舁アレルギ一症 状発現場所は，リンゴ烟106世带 $(79.1 \%)$ ，戸内 3 世 带，不定 26世带て，期闆はりンゴ開花期のみが99世带
表 1 アンケート用紙 リンゴ北䎦症フンクート用綎

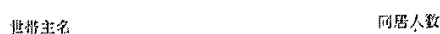

$$
\begin{aligned}
& \text { it } m
\end{aligned}
$$

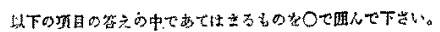

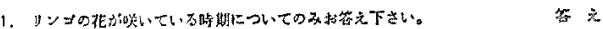

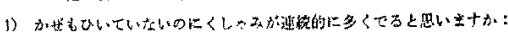

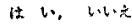

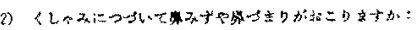
(2)

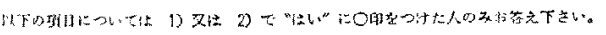

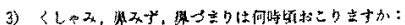

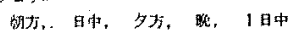

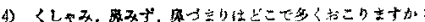

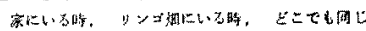

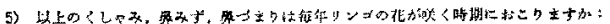

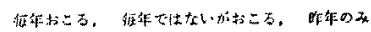

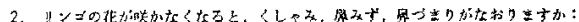

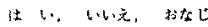

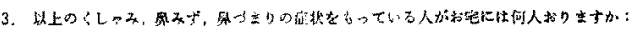

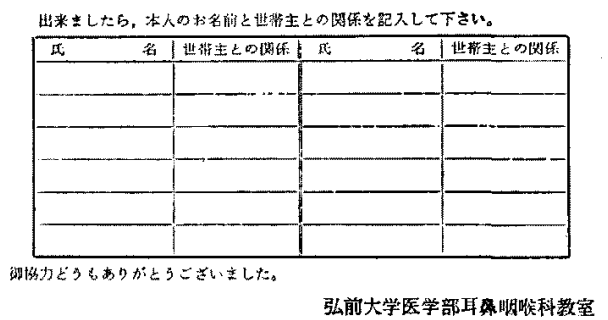

(73.9\%)て，さらに症状が持続するという人のいる世带 は30世带であった。

これらアンケート調查の結果より，著者は134世带385 人をリンゴ花粉症の疑いありとして，平賀町在往の115 人に対して，1978年5月29日と6月5日の2 日間平賀 町立病院に叔いて，鼻アレルギー検部を行なった。

検查項目は，1）鼻アレルギー問診，2）前鼻鏡検查， 3）舅汁中好酸球数検查，4）血中好酸球数検查，5）リ ンゴ花粉彰断用アレルゲンエキス 1,000倍による皮内テ ストであり，検診参加者29名中，10名が皮内テスト陽性 であった、しかしながら，当日は全例共に舅内所見が舅 誘発テストに不適なため，リンゴ花粉エキス10倍溶液を コントロール・ディスクに滴下し，風乾したものを用い た鼻誘発テストは後日行ない，全例共に陽性であったた め，この10名をりンゴ花粉症と診断した．これら10症例

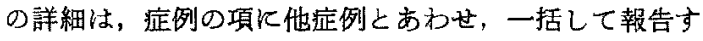
๖.

$$
V \text { 症例 }
$$


表 2 生活および環境因于

\begin{tabular}{|c|c|c|c|c|c|c|c|c|c|c|c|}
\hline & 年合 & 性 & 作所 & 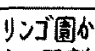 & & リン & ว"ᄉI & 交配 & 31 & $\theta^{\circ}-$ 歴 & 登症 \\
\hline No & 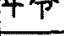 & 恃 & $1 \pm \pi \eta$ & & 咟美 & & 年数 & 登症 & & 家族歷 & 誇园 \\
\hline 1 & 32 & 우 & 相馬村 & $300 \mathrm{~m}$ & りうコ费業 & + & 7 & 年 & - & + & 不明 \\
\hline 2 & 55 & $\delta$ & 黑石市 & 150 & リ疒浀莱 & + & & & - & + & 不明 \\
\hline 3 & 37 & q & 浪为町 & 10 & 江㤟業 & + & 10 & 0 & - & + & 転職 \\
\hline 4 & 33 & 오 & 鿖石村 & 5 & 主婂 & + & & & - & - & 不明 \\
\hline 5 & 26 & 우 & 胎前市 & & 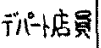 & - & & & - & - & 外まいり \\
\hline 6 & 47 & $\delta$ & 平質町 & 150 & リンゔ曹業 & + & 22 & 19 & - & - & 人士交配 \\
\hline 7 & 50 & 우 & 黑石市 & 500 & りうコ蕽業 & + & 20 & 12 & - & - & 人工交配 \\
\hline 8 & 41 & 우 & 藤崎町 & 5 & 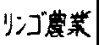 & + & 15 & 7 & + & - & 人工交配 \\
\hline 9 & 33 & 우 & 平賀朾 & 100 & リンゴ费業 & + & 12 & 7 & - & + & 不明 \\
\hline 10 & 32 & 우 & 平賀朾 & 100 & 归曹業 & + & 10 & 4 & - & - & 人工交配 \\
\hline 11 & 42 & s & 平賀町 & 3 & 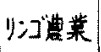 & + & 20 & 0 & $\begin{array}{lll}- & \\
\end{array}$ & - & 不明 \\
\hline 12 & 46 & 우 & 平賀町 & 200 & 归曹䅈 & + & 10 & 6 & + & - & 人工交配 \\
\hline 13 & 42 & $\delta$ & 平賀朾 & 100 & リン橪業 & + & 19 & 4 & + & + & 人工交配 \\
\hline 14 & 43 & 우 & 平賀町 & & リンゴ曹紫 & + & & & - & - & 人工交配 \\
\hline 15 & 46 & $\delta$ & 平賀町 & 100 & 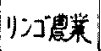 & + & 25 & 15 & - & - & 不明 \\
\hline 16 & 33 & $\delta$ & 平賀町 & 20 & 肜莦萧 & + & 10 & 0 & + & - & 除 草 \\
\hline 17 & 29 & 우 & 平賀町 & 300 & 北曹業 & + & 7 & 3 & - & + & 人工交配 \\
\hline 18 & 32 & 우 & 板柳町 & 50 & 商店員 & + & 10 & 6 & + & + & 人项配 \\
\hline 19 & 11 & s & 木造町 & 150 & (小学生) & - & & & - & - & 部活動 \\
\hline 20 & 32 & 우 & 板柳町 & 20 & 汀曹虽 & + & 15 & 10 & + & + & 不明 \\
\hline 21 & 29 & 우 & 浪用町 & 2 & ע江㤟業 & + & 11 & 9 & - & + & 出夝 \\
\hline
\end{tabular}

当科鼻アレルギー外来を中心に本症と診断された 21 症 例火ついて，環境因子，発作状態，アレルギー検查成 績，拉よび治療について検討を加えてみた。

1. 環境因子

症例の年跡，性別，住所およびリンゴ園から自宅まで の距離, 職業並びに感作の原因と考えられるリンゴ人工 交配の実想等を第 2 表に示した.

当科初診時年齢仿11-55藏で，男 7 例 女 14 例で $1: 2$ の割で女性飞多く，発症年龄は10-45歳で20歳台の発症 が $52.4 \%$ と最多を占め，発症平均年龄は 30.2 歳であっ た.

症例の居住地は津轻地方20例, 南部地方 1 例で，これ は当科診療圈の関係から津軽地方に多いのであるが，南 部地方飞む別仁本症の報告はある゙。.これら症例の自宅 からリンゴ園までの距離を第 2 図に示したが，これによ ると，全例リンゴ園より $500 \mathrm{~m}$ 以内居住しており，特 飞50m以内では, リンゴ花粉空中飛散曲線上り, 自宅で あ十分化感作される可能性はあると推察されて。

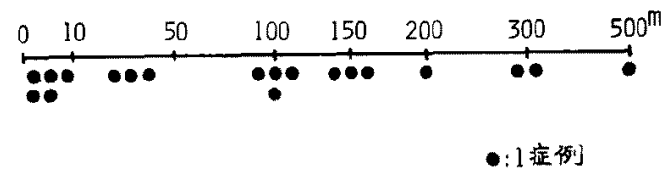

図 2 患者自宅加らンン゙園までの距雄

さて，21症例中 17 症例（81.0\%）がリンゴ農業従事者 であり，19症例（90.5\%）がリンゴ人工交配を経験して いる，安のリンゴ人工交配の経験年数は，7-25年で， 平均 14.4 年であり，最初の人工交配経験後0-19年， 平均年数として 6.8年で本症の発症をみている.

また，アトピーの瞄往歷は $28.6 \%$ ，アレルギー性

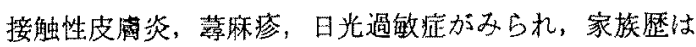
$42.8 \%$ でレルギー性鼻资が大部分であった。

\section{2. 発作状熊}

本症例の発作状態について覓症状を中心第 3 表儿示 した.

発作期閻中でもリンゴ開花期である 5 月上旬から 6 月 
表 3 発 作 状 的

\begin{tabular}{|c|c|c|c|c|c|c|c|c|c|}
\hline \multirow{2}{*}{\multicolumn{2}{|c|}{\begin{tabular}{l|l} 
No 発症 \\
年
\end{tabular}}} & \multirow{2}{*}{$\begin{array}{ll}\text { 発 } & \text { 作 } \\
\text { 期 } & \text { 間 } \\
\end{array}$} & \multirow{2}{*}{\multicolumn{2}{|c|}{ 状洗 }} & \multirow{2}{*}{ 全 症 状 } & \multicolumn{2}{|c|}{ 䨢 } & \multicolumn{2}{|r|}{ 状 } \\
\hline & & & & 場所 & & 〈l6子 & 高渴 & 量閉 & 重症度 \\
\hline 1 & 29 & 5月上旬 7月初旬 & $18 中$ & 㠺ン゙圆 & R. O.Ro, & ++ & ++ & ++ & 中等症 \\
\hline 2 & 45 & 4月下旬 7 月中旬 & 18 中 & 不定 & R. O,Ra,D. & +++ & +++ & +++ & 重症 \\
\hline 3 & 27 & 5月上旬 8月末 & 1日中 & !リンコ图 & $R, 0, R a, D$. & +++ & $++t$ & +++ & 重 症 \\
\hline 4 & 33 & 5 月中旬 7月中旬 & 朝，访 & 不定 & R.O.D. & +++ & +++ & +++ & 重症 \\
\hline 5 & 25 & 5 月上旬 7月上旬 & 1日中 & 不定 & R.O.D. & + & + & ++ & 中等症 \\
\hline 6 & 44 & 5 月上旬 $\sim 6$ 月中旬 & 1 日中 & 江江圆 & R. 0 , Ro. & +++ & +++ & ++ & 重症 \\
\hline 7 & 42 & 5月上旬～7月末 & 1 日中 & リ氺葍 & R.0.D. & +++ & +++ & ++ & 重 症 \\
\hline 8 & 33 & 5月中旬 $\sim 6$ 月末 & 1 日中 & 不定 & R.0.A. & +++ & +++ & ++ & 重 症 \\
\hline 9 & 28 & 5月初旬 6月末 & 朝.日中 & 不定 & R. 0 . & ++ & +++ & + & 中等症 \\
\hline 10 & 26 & 5 月初旬 $\sim 7$ 月中旬 & 1日中 & リンコ固 & R.O.H. & ++ & $++t$ & +++ & 重症 \\
\hline 11 & 20 & 4月下旬 9月末 & 1日中 & U二间自安 & R.0.RO.D. & +++ & ++ & +++ & 重症 \\
\hline 12 & 42 & 5月上旬 6月上旬 & 日中 & 訂固·自宅 & $R .0 . R$ & ++ & +++ & - & 中等症 \\
\hline 13 & 30 & 4月末束 6月下旬 & 1日中 & リン门園 & R. 0 . & +++ & $++t$ & ++ & 重症 \\
\hline 14 & 35 & 5月上旬 一 10月末 & 日中 & 江圊·自宅 & R. 0 . & +++ & +++ & ++ & 重症 \\
\hline 15 & 36 & 5月上旬 7月末 & 日中 & 过圈自己 & R.O.H.D. & +++ & +++ & ++ & 重症 \\
\hline 16 & 25 & 5月上旬 6月末 & 朝 & 不定 & R. 0 . & +++ & +++ & + & 重症 \\
\hline 17 & 25 & 5月上旬 7 月中司 & 日中.9万 & 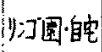 & R. 0.Ro. & +++ & +++ & ++ & 重症 \\
\hline 13 & 25 & 5 月上旬 一 6月初旬 & 朝，日中 & 订遇的宅 & $R, O, R O, H . G$, & +++ & +++ & + & 重症 \\
\hline 19 & 10 & 5 月下旬 $\sim 6$ 月末 & 朝，日中 & 自宅·学校 & $\mathrm{R}, 0 . \mathrm{H}$ & + & ++ & + & 㪕症 \\
\hline 20 & 27 & 5 月上旬 $\sim 6$ 月末 & 1日中 & 㓅圈自它 & $\mathrm{R}, 0 . \mathrm{H}$. & +++ & +++ & ++ & 重症 \\
\hline 21 & 27 & 5月上旬～8月初旬 & 1日中 & リン゙園 & R.O.H. & +++ & $++t$ & $++t$ & 重症 \\
\hline
\end{tabular}

R，鼻症状，O，眼症状，Ra，咽嘼症状，D，皮虚症状，A，喘息症状，H，咳嗽，G，颜面脽脹。

初旬までは症例增悪が著明で，総して6月末末で症状の 持続する症例が多く，さらに，リンゴ開花期前，扣よび 7一10月にかけてむ症状が持続する症例は他の花粉症上 の合併委考虑しなけれはならないと思われる。

発作時間带は1 日中が $57.1 \%$ と最多であるが，リン ゴ園で作業する日中に旋状が最も增悪することが問㟝よ り判明した.

また，発作発現場所は，リンゴ園 $66.7 \%$ ，リンゴ園 々自宅の雨方阮 $33.3 \%$ ，他飞，外勤時， 戸外での部活 動時という場合もある。

発作期の症状は，鼻症状括上び眼症状が全例䎲認めら れ，次いて咽頍症状（咽頭痛，咽頭掻痒感） $38.1 \%$ ，咳 濑 $33.3 \%$ ，皮苚症状 $28.6 \%$ の順であり，而息発作や顔 面浮腫を証める症例も存在した，算症状法舅閉上りくし

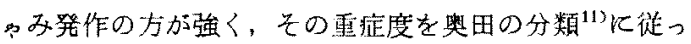
て分類してみると，重症 76.2\%，中等症 $19.0 \%$ ，軽症
4. $8 \%$ あっった.

\section{3. 椧查成績}

発作時のアレルギー 検查成績の概要を第 4 表に示し た。

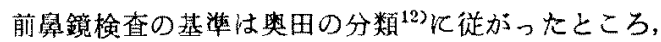
花粉症例飞対する諸家の報告と一致し，下甲仝浮腫状腫

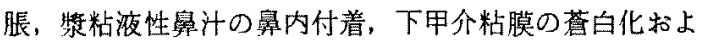
び急性炎症に上る発赤が認められた。

鼻计好酸球数の基愺は奥田の grade 法 ${ }^{13)}$ 飞従がい， その結果は 卅が 30\%, 故 15\%，十が 35\%，一が 20 \%で，血中好酸球数は 1 -17\%で，平均 $5.6 \%$ で た.

皮内テストは，リンゴ花粉エキス1000倍溶液（PNU は $2.40 \mathrm{\mu g} / \mathrm{ml}$ ) と石松子エキス 1000 倍溶液（PNU は $0.01 \mu \mathrm{g} / \mathrm{m} l)$ l) 2 種類飞，同時期飛散花粉エキス数種を

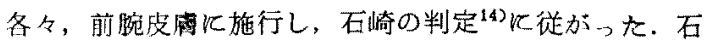


表 4 榆 查 成 績

\begin{tabular}{|c|c|c|c|c|c|c|c|c|c|c|}
\hline N & 前 & 臬 & 模直 & 好酸 & 球数 & 二皮 太 & テスト & 兽落登 & $\operatorname{Ig~E}$ & IgE抗体 \\
\hline & 腄脸 & 汁 & 色詞 & 帛汁中 & 血申 & 㹝花粉 & 他の㜢性搌原 & 于x $x$ & (RIST) & (RAST) \\
\hline 1 & ++ & $\mid$ 付(装) & 赤 & +++ & $4 \%$ & +++ & RW. & ++ & 1392 & 2 \\
\hline 2 & + & |付(韭)| & 门す赫 & & 2 & ++ & $R W_{2}$ & ++ & 965 & \\
\hline 3 & + & 中(浆) & 印塔白 & + & 2 & +++ & OG.HD. & $+t+$ & 52 & 1 \\
\hline 4 & +++ & 付(浆) & う吉赤 & + & 6 & + & HD. & + & 201 & 0 \\
\hline 5 & ++ & 付(殞) & 赤 & ++ & 5 & + & HD.C.JC. & ++ & 457 & \\
\hline 6 & +++ & $中\left(\begin{array}{l}* \\
*\end{array}\right)$ & 赤 & $t+t$ & 8 & ++ & & ++ & 537 & 1 \\
\hline 7 & ++ & 付(挤) & 赤 & + & 3 & + & & + & 102 & \\
\hline 8 & +++ & |讨(㪍) & 赤 & + & 1 & +++ & & + & 115 & 1 \\
\hline 9 & t+t & 充捊 & 蓉白 & ++ & 12 & t+t & OG. & ++ & & 1 \\
\hline 10 & t+t & 充(活) & 莟白 & +++ & 10 & +++ & 06. & ++ & 620 & 3 \\
\hline 11 & +++ & 充(粘) & 莬白 & ++ & 6 & +++ & & ++ & & \\
\hline 12 & +++ & 中(䈋) & 赤 & +++ & 12 & +++ & & ++ & & \\
\hline 13 & ++ & 付(採) & うす赤 & +++ & 17 & +++ & & +++ & & \\
\hline 14 & +++ & 中(潾) & 猎赤。 & + & 4 & ++ & & ++ & & \\
\hline 15 & ++ & 中(㯆) & 暗赤 & - & 8 & ++ & & ++ & & \\
\hline 16 & +++ & 中(粘) & 暗赤 & + & 2 & +++ & & ++ & & \\
\hline 17 & ++ & 付粘) & 赤 & + & & +++ & & ++ & & \\
\hline 18 & - & 無 & うす未朱 & - & 4 & + & OG.HD.C. & ++ & & \\
\hline 19 & ++ & 付裙) & 种荅白 & - & 3 & + & RW. & + & & \\
\hline 20 & $++t$ & 無 & 赤 & - & 1 & ++ & $0 G$. & + & 475 & 0 \\
\hline 21 & + & 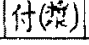 & 过赤 & +++ & 1 & ++ & 06. & ++ & & 2 \\
\hline
\end{tabular}

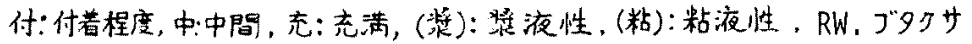

OG、カモガヤ、HD、ハウスタスト，C、カシジダ，JC、スギ

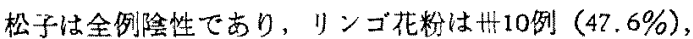
\#6例 $(28.6 \%)$ ，＋5例 $(23.8 \%)$ であった。 ま。， 鼻誘発テストの判定は第12回日本鼻副㽡腔学会パネルデ ィスカッションの評価基準 ${ }^{152}$ に準したところ、姍 2 例 $(9.5 \%),+14$ 例 $(66.7 \%)$, + 5 例 $(23.8 \%)$ であ, た.

発作期の血清 total Ig E (RIST) U $52-1392 \mathrm{u} / \mathrm{m} l$, 平均 $484 \mathrm{u} / \mathrm{m} l$ であり, 韭発作期は $108-2200 \mathrm{u} / \mathrm{m} l$, 平 均 $549 \mathrm{u} / \mathrm{ml}$ で, 季節的変動は認められなかった。

IgE 抗体测定(RAST)は，宮本ら ${ }^{16)}$ の方法に従がっ て自家製リンゴ花粉ディスクを作成し，シオノギRAST キッド添代の reference 血清の基濣に則り分類した結 果, Class $3: 1$ 例 (11.1\%), Class $2: 2$ 例 $(22.2 \%)$, Class $1: 4$ 例 (44.4\%), Class $0: 2$ 例 (22.2\%) て あった。これらの中て自然感作群法 Class $3-1$ まで 各 1 例であり，同時に行なったイネ科花粉重複怔例の八
ルガヤ，ギョウギシバ，力モガヤ，ナガハグサのRAST 值化して低值示した。

\section{4. 治療}

本症の治療はリンゴ花粉による特異的減感作療法を第

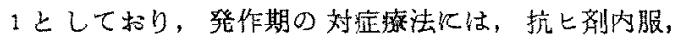
Disodium Cromoglicate (DSCG) 点鼻, 血管収縮副点 舅，ステロイド剂鼻ネブライザー療法を行なっている。 また，監息発作合併症例にステロイド内服（プレドニン $5 \mathrm{mg}$ 連日 2 週間投与)を行ない，発作を抑制していた。 これらの治療内容 (20症例) は，リンゴ花粉減感作痖法 7 例 $(35 \%) ， D S C G$ 投与 10 例 $(50 \%)$ ，抗七剂投与 18 例 $(90 \%)$ ， ステロロド内服之非特暴的減感作療法が各 1 例である。

リンゴ花粉減感作症例の治療概要は第 5 表に示したご とくであり，リンゴ花粉治療用エキスる同值下100倍よ り皮下浇く注射する万法で閏始し，次発作期前に100店 
表 5 減 感 作 症 例

\begin{tabular}{|c|c|c|c|c|c|c|c|c|}
\hline \multirow{2}{*}{ No. } & \multirow{2}{*}{ 症状 } & \multirow{2}{*}{ 重症度 } & \multicolumn{4}{|c|}{ 療 法 } & \multirow{2}{*}{$\begin{array}{ll}\text { 併 } & \text { 用 } \\
\text { 糜 }\end{array}$} & \multirow{2}{*}{ 治 廛 効 果 } \\
\hline & & & 開 始 & 現在 (1979 & .5) & 年数 & & \\
\hline 1 & R.O. RO. & 中等症 & 10 万锫 & 100倍 & (維) & 2.5年 & 抗ヒ・DSCG & 作業中症状改善 \\
\hline 2 & R.O, RO,D. & 重 症 & 10 万培 & 20倍 & （維） & 4.8 年 & & 作業中も症状なし \\
\hline 3 & R.O. RO,D. & 重 症 & 1000 万倍 & 矤 0.1 & （雓） & 3 年 & 上 剂 & 作業中症状わすか \\
\hline 4 & R.O. D. & 重 & 1 万倍 & 100 倍 & （維） & 1.8 年 & 抗 七 殽 & 発作期に症状なし \\
\hline 6 & R.O. Ra. & 重 症 & 1 兆倍 & 100 倍 0.02 & (上) & 0.7 年 & DSCG & 作業中症状改䈍 \\
\hline 8 & R.O.A. & 症 & 憶培 & 100 倍 0.05 & ( 維) & 1.9 年 & 抗七・DSCG & 喘息発作改羓 \\
\hline 19 & R.O.H. & 症 & 100 万倍 & 10 万倍 0.2 & $($ 上) & 0.3 年 & DSCG & 昨年より症状改善 \\
\hline
\end{tabular}

（維）：維持療法 (上)：維持㗫法前段階

$0.1 一 0.3 \mathrm{~m} l$ 反達するのを目標にし，それ以後牥，発作 期をさけて維持量を 2 力月に 1 回の割で注射する方針て 行なってきた。この減感作療法は，本症例中でも重症打 よび発作期間が長期（1力月以上）飞わたる症例行な うことを原则としている。第 5 表に示す様に，治療閒始 後の次発作期仙は作業中のくしゃみ発作および按鼻回数

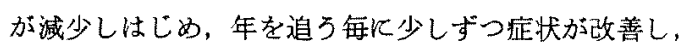

4.8 年行なっている症例 2 は現在, リンゴ園ての作業中 亿む症状方出現しない，症例 4 はりンゴ園近住の患者て あるが，隇感作療法を行なってからは，リンゴ開花期保 症状を認めなくなり，喘息発作を合併した症例 8 には， ステロイドの減量成功しこれらの経験より本症に招 いて特異的琙感作燎法が有効であるとの印象を得た。

な抢，短期間発作症例化対し，DSCG 療法を陚み。く しゃみ発作の柽減, 按鼻回数の減少をみたが, 未だ検討 の余地はあると思われ，このこと関しては機を改めて 報告する予定である。

\section{II 考按}

本邦に和ける花粉症報告は枚挙にいとまがないが，栽 培植物の花粉症となるとその報告数は少ない。著者が道

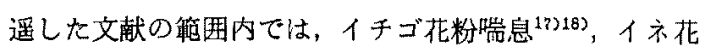
粉嵒息 ${ }^{193}$, テンサイ花汾症 ${ }^{203}$, シイタケ胞子而息 ${ }^{21222)}$, 除虫菊花粉症 ${ }^{23}$ 等であり, リンゴ花粉症も穴の一例であ る.

本症注1974年坂本（未発表）による診断と治療が本邦 最初上思わ机るが，その後，加藤ら ${ }^{24}$ が長野県に打ける 花粉症の一種として予報を出し，また，沢田 ${ }^{25) 283}$ は弘前 市近郊のりンゴ農業従事者の中上り5例を発見して疫学
的検討を加えている。

花粉症の発症条件について, Thommen ${ }^{272}$, 上野 ${ }^{282}$ か $^{2}$ 記载しているが，いずれる風媒花を对象としたものであ る.しかし，Gratter ら $5^{299}$ 䖵媒花でも花粉症の発症す

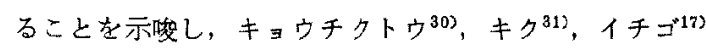
${ }^{182}$ ，除虫菊 ${ }^{23}$ 等の蝶花花粉症の報告も現にある. 小 林ら ${ }^{18)}$ は虫媒花であっても，作業時に花粉を吸入した り，衣類や身体に付着すれば容易に感作されるといい， 松山ら ${ }^{20)}$ 寺尾ら $^{17)}$ はビニールハウスといろ泌室でた 卜上植物が近接した状態が続くなら，必ずしも卮媒花で なくとむ，また花粉量が多くなくとも花粉症は発生する 之思うと述へ，藤崎ら ${ }^{32}$ は虫媒花に上る発症は，植物の 種類, 花粉との接触量, 接触距襍, 接触期間（または時 間）などによるが，その極端な例がビニールハウスまた は温室栽培によるものでるろと推察を加えている、リ ンゴは蝶花であり，その花粉空中飛散曲線より推測す れば，リンゴ園内では多量の飛散が考えられる。そのよ

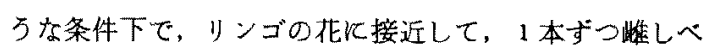
に花粉を付着させる作業を長時閔行なうリンゴ人工交配 作業は十分にリンゴ花粉に感作され得る条件の場を提供 すると思われる。沢田 ${ }^{25}$ )はリンゴ花粉症の発症には全例 が10年以上経過し，リンゴ花粉による感作成立，発症ま でにはかなりの年数を必要とするのであるうと推論して いるが，著者の症例は初回リンゴ人工交配後平均 6.8年 で発症して括り，初年発症例が 3 例， 5 年以内の発症例

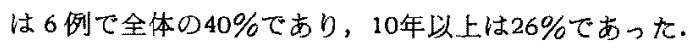

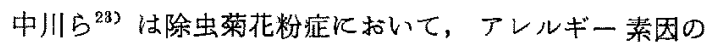
ある者は 2 年位で発症すると述へ，著者も本症は強烈な 花粉曝露である人工交配作業を行ならリンゴ農業従事者 
でアレルギー秦因があれば，すぐに発症する可能性は十 分にあり，人工交配の作業条件はビニールハウスまたは 温室内の条件に匹敵すると思われる。一方，人工交配炕 常時従事していない付近住民の発症はどの上う化考える ベきか，著者の行なったリンゴ花粉空中飛散調查より， リンゴ花粉は $1 \mathrm{~km}$ の地点ですその飛散か確認されてお り，しかる，リンゴ園より自宅までが $5 \mathrm{~m} ， 50 \mathrm{~m}$ また， 小学生の場合は通学路拈よび学校付近にりンゴ園ありと の事で,リンゴ園外への花粉飛散による感作が考光られ， 本症がリンゴ農業従事者とリンゴ園付近の住民住㑇如 れるといら点は中川の埌告した除虫菊花粉症にきわめて 類似している.

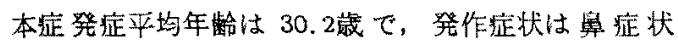

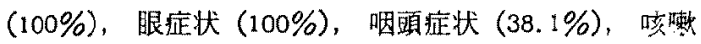
(33. 3\%)，皮症症状 $(28.6 \%)$ の順で，喘息例も認めら れ，この症例は中村 ${ }^{33}$ 亿よる職業性花粉蛗息飞該当する あのと思われる. 學症状は，くしゃみ・䑁漏型が大部分 で鼻閉型は注とんどなく，重症例が $76.2 \%$ 発作時の 症状は強烈であるが，付近の住民よりはリンゴ農業従事 者の方江重症例加多く、こ机は吸入抗原量の多少化上る るのと思われる。

血清 total IgE (RIST) は 52-1392 u/ml, 平均 で $484 \mathrm{u} / \mathrm{m} l$ と，必ずしも高值を示しては拈らず, 症例 1 の $1392 \mathrm{u} / \mathrm{m} l$ が最高であるが，同症例恃非発作期でむ $2200 \mathrm{u} / \mathrm{m} l$ を示している。 沢田の 5 例は 300-1160u $/ \mathrm{m} l$ で，平均 $625 \mathrm{u} / \mathrm{m} l$ と著者の症例上りやや高值を示して いる. 著者の IgE 測定例は，その多くがリンゴ花粉に 上る特異的隇感作療法を受けて打り，季節差飞括ける $\operatorname{IgE}$ の著明な变動は認められなかった。

以前は，本症例飞対し，P-K洒測定を行なっていたが， 最近は感染等の諸問題により，自家製リンゴ花粉ペーパ 一・ディスクを作成し，RAST 法により IgE抗体を測 定している. 本症でイ京科花粉症の合併例飞対して，同 時にイネ科花粉の RAST 值測定を行なった結果，リン ゴ花粉の RAST 值の方が低く、これらより、リンゴ花 粉の抗原性はイネ科植物より低いると思われる。

本症炕対する特異的隇感作療法は，原則として，重症 でかつ長期間発作例（1 力月以上）飞対して行なってお り，皮下注射法で，闌值下 100倍上り開始し，100倍0.1 一 $0.3 \mathrm{~m} l$ を維持量の目安として, 継続的療法の形をとっ ている，本症の場合，翌シーズンより症状の軽減をるる が，2シーズンを経過すると，発作期でる日常生活炕さ しつかえなくなる，奥田 ${ }^{34)}$ は花粉症では一般に特異的減
感作療法の治瘵成綪は芳しくないとして，ハウスダス卜 の79.7\%の柽快率飞対して，スギ $29.9 \%$ ，1不科 18.2 \%とのデータを示し，特異的減感作療法炕固執すべで

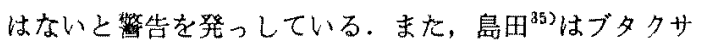

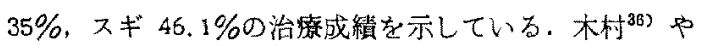

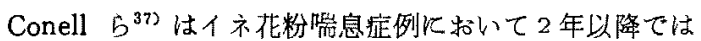
良好な成績が得られたと報告している，著者は，現在ま での治療経験より，本症で特買的隇感作療法が有效で あると考えている.

\section{VII 結語}

青森県下に括ける21例のリンゴ花粉症例を報告する上 共に，種々の調查により，本症の実態を明確にした。

1. リンゴ花粉は 3 揅孔粒指紋状紋の形態を成し， 28

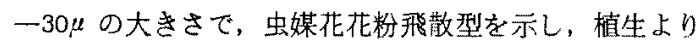
$1 \mathrm{~km}$ 地点に打いても飛散を認めた。

2. リンゴ農業從事者约招いてリンゴ開花期（5月上 旬一 5 月末）飞鼻アレルギー症状が発現する人は $14.6 \%$ であった。

3.リンゴ農業従事者でリンゴ花粉症の疑いのある29 名を対象として鼻了レルギー検䧐を行ない，10名のリン ゴ花粉症例を発見した。

4. 本症例は，リンゴ農業徒事者扔よびリンゴ園付近 の住民であり，その発症平均年岭は 30.2 瓷であった。リ ンゴ人工交配経験者は初回作業経験後平均 6.8 年で発症 して和り，初年発症者が 3 例存在した。な特，アトピー の既往歴は $28.6 \%$ ，家族歴は $42.8 \%$ でる.

5. 本症の感作成立は，リンゴ人工交配時及びリンゴ 園外へのリンゴ花粉飛散によるものと考元ら扎前者は， ビニールハウス括よび温室栽培に打ける条件に匹敵し， 後者は除虫菊花粉症の㬰態江合致する。

6. 本症の発作期間はリンゴ開花期江一致し，鼻症状 (100\%), 眼症状 (100\%), 咽頭症状 (38.1\%) 加主体 で, 疾症壮重症属するものが多い。

7. 発作時の血中好酸球数は $5.6 \%$, 血清 total IgE (RIST) は $484 \mathrm{u} / \mathrm{m} l$ で季節的変動は認めなかった。な 招，IgE抗体価（RAST）低低く，1亦科植物上り抗原 性啊弱いと考兄占机る。

8. 本症の治療注，リンゴ花粉による特異的減感作 療法が有効と思われる。 


\section{参考文 献}

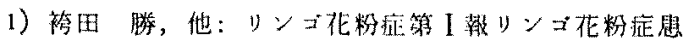
者の稆介 月只篎 82:511-511，1979.

2）熊代克己：甘界の植物一ナナカマド, リンコー 朝日百科 55：1304-1308, 1976.

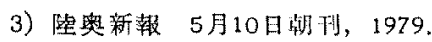

4）幾瀨 マ+：日本㨁物の花粉広川泪吉：1-277, 1956 .

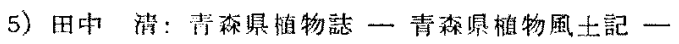
東奥日報补：201-205，1975。

6) American Academy of Allergy: Preliminary Report of the National Pollen Survy comittee of the American Academy of Allergy on Proposed Standardization of Pollen Counting Techniques, J. Allergy, 17: 173-177, 1946.

7) 降失和夫: 花粉症比関する研究一相慔原市に招け る空中花粦の調查成繢 アレルギー 16:277-288， 1967.

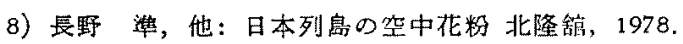

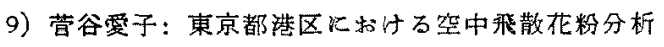
特にイチョウ花粉の飛散状態について アレルギー 22: 321-327, 1973.

10）袺田勝，他：当科火和ける花粉症の検討 弘前医 学 投稿中, 1979 .

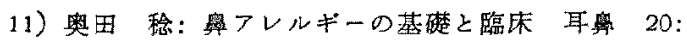
$297-344,1974$.

12）奥田 稔, 他: Disodium Cromoglicate（インター

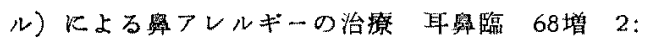
395-425, 1975.

13）奥田 稳：奥アレルギー診療の赛際 金原出版, 1975.

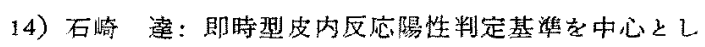
て アレルギー 12:14-30, 1963.

15）打越 進：辤アレルギ一の治療 治療好果の判定 日本舅副鼻腔学会々誌 $12 ： 16-16,1973$.

16）宮本昭正, 他：Paper Disc を用いての Rasioallergosorbent Test (RAST) K開西研究 アレルギー 22: $584-593,1973$.

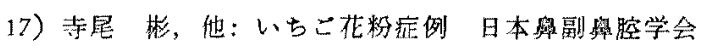
々 率 11: 51-52, 1972 .

18）小林敏男，他：イチゴ花粉に上る喘息症例と乞の疫 学的調楂てレルギー 22: 699-705, 1973.

19）木村利定，他：小思気管支圌息のフレルケン耪断と

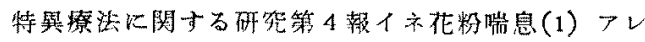

ルギー 20:903-914, 1971.

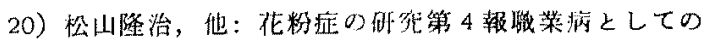
テンサイ花粉症 フレルギー 21：235-243，1972。

21）七条小次即, 他: しいたけ胞子喘息の1例日内会 誌 $58: 35-39,1969$.

22）近蕃忠钿：しいたけ胞子楳息の1例フレルギ$18: 81-85,1969$.

23）中川佼二, 他：除虫菊花粉症についてアレルギー $24: 352-353,1975$.

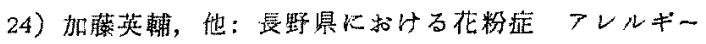
27: $374-374,1978$.

25）沢由芧讯：リンヨ花粉症について フレルギー27: $815-817,1978$.

26）沢田幸正：蜮荣性リソゴ花粉症 産菜医学 20：382 $-383,1978$.

27) Thommen $H$ : Practice of Allergy (Vaughan and Black). C. V. Mosby, St. Louis: 442-443, 1957.

28) 上野実朗: 花粉学研究風間電居, 1978 .

29) Gratter, W.C. and Stemen, T.R.: The plant the pollen and the patient. Paleobot Palynol. 4: 187 $-188,1967$.

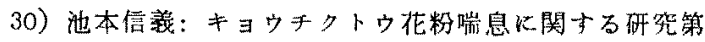
1 報 キョウチタトウ花粉（雄しべ）フレルゲン以 ついて アレルギー 19: 188-192, 1970.

31) 神辺 竓, 他：キク花粉症 アレルギー 23:248249,1974 .

32）莱崎洋子，他：花粉症の研究目花粉の飛散型につ いて アレルギー 24:613-628, 1975.

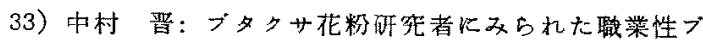
タクサ花粉症例 アレルギー 24:599-603，1975.

34）奥田稳，他：礐フレルギ一免疫療法の遠隔成維 耳展 21：144-147，1978.

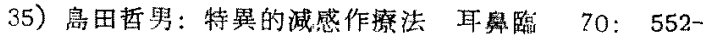
$555,1977$.

36）木村利定：1ネ花粉喘息の研究第 3 報イネ花粉工 キスによる特珙的減感作镣法の成績 アレルギー 26: 475-484, 1977 .

37) Conell, J.T, and Sherman, W.B.; Changes in skinsensitizing antibody titer after injection of aqueous pollen extract. J. Allergy 43: 22-32, 1969. 


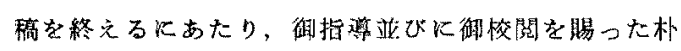

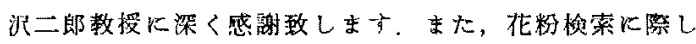

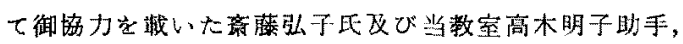

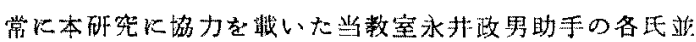

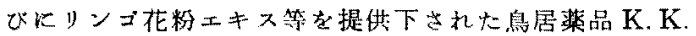
に梁搠いたします。

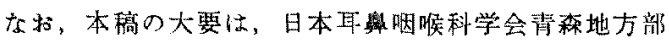
会第9，11，12回例会，第17回日本奥副舆舜学会，第88

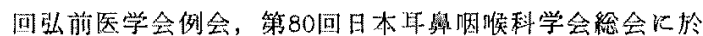
て曰旗した。

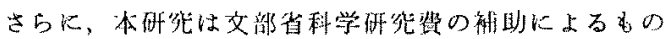
でる。

(原满受付 照和54.9.3日)

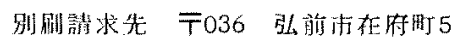

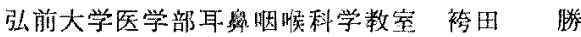

